\title{
PENGARUH BUDAYA ORGANISASI, LINGKUNGAN KERJA, DAN KOMPENSASI TERHADAP KINERJA KARYAWAN KOTA MOJOKERTO
}

\author{
Galuh Yuliana Dewi \\ Universitas Islam Negeri Sunan Ampel Surabaya \\ e-mail: galuhyuliana146@yahoo.com
}

\begin{abstract}
This research is quantitative research that emphasizes its analysis of numerical data (numbers) processed by statistical methods. The goal is to know if there are influence between organizational culture (X1), work environment (X2), and compensation (X3) of the employees performance in PT. BPRS Mojokerto City. The sample used in this research were 38 employees. From the results of research above can be concluded that there is positive and significant influence partially on cultural organization variables. Variable (X1) on employees performance (Y) in PT. BPRS Mojokerto City is $0.016>0.05$ and the value of $t$ count $>t$ table is 2,546>2,028. Then, from the result test on the working environment variable (X2) against $Y$ is $0.009<0.05$ and the values of $t$ count is $2.763>2.028$. There is positive and significant partially effect of variable work environment (X2) of employees performance (Y) in PT. BPRS Mojokerto City. Then, the result of compensation (X3) effect of performance $(Y)$ variable in PT. BPRS Mojokerto City is negatif and not significant partially. The value is $0.826>$ 0.05 and t counted $0.221<t$ table 2,028. At the $f$ test counted 9,309 so that the $f$ count > f table is $9.309>2.87$, and the p-value (sig) counted $0.000>$ less than 0.05. Thus, organizational cultural variables (X1), work environment (X2), and compensation (X3) have simultaneous effect on employees performance $(Y)$ in $P T$. BPR Syariah Mojokerto City.
\end{abstract}

Keywords: organizational culture; work environment; compensation; performance

\section{Pendahuluan}

Salah satu faktor penting dalam suatu organisasi perusahaan adalah sumber daya manusia. Salah satu contoh sumber daya manusia dalam suatu perusahaan adalah karyawan. Sebuah perusahaan tidak dapat beroperasi jika tanpa adanya sumber daya manusia, sehingga sumber daya manusia merupakan faktor penentu keberlangsungan hidup suatu perusahaan. Apapun bentuk dan tujuan organisasi dalam sebuah perusahaan tidak akan pernah lepas dari karyawan. Keberhasilan suatu perusahaan tidak pernah lepas dari kinerja karyawan. Allah berfirman dalam:

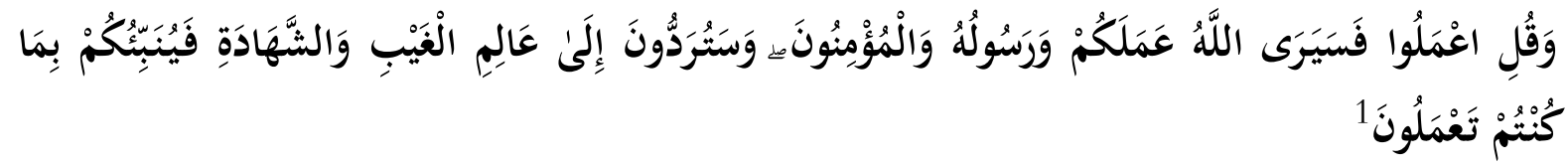

"Dan katakanlah: Bekerjalah kamu, maka Allah dan rasul-Nya serta orang-orang yang mukmin akan melihat pekerjaanmu itu, dan kamu akan dikembalikan kepada Dzat yang mengetahui akan yang ghaib dan yang nyata (Allah), lalu diberitakan-Nya kepada kamu

\footnotetext{
${ }^{1}$ al-Quran, 9: 105.
} 
apa yang Telah kamu kerjakan.”

Dari ayat di atas dapat diartikan bawa kata 'amalakum yang berarti amalmu atau pekerjaan. Kata 'amalan atau pekerjaan itu adalah kinerja dari seseorang. Kinerja seseorang dapat dilihat dari seberapa baik seserang melakukan tugas dan memenuhi tanggung jawab perusahaan. Kinerja karyawan dengan kinerja perusahaan akan memiliki hubungan erat jika dalam suatu perusahaan memiliki karyawan yang mempunyai kriteria-kriteria yang baik. ${ }^{2}$ Peningkatan kinerja karyawan akan mendorong kemajuan bagi organisasi di lingkungan perusahaan untuk dapat bertahan dalam suatu persaingan kerja. ${ }^{3}$ Sebaliknya, rendahnya kinerja karyawan akan mempengaruhi kualitas dan kuantitas perusaan dalam suatu bisnis.

Perkembangan perbankan syariah sangatlah pesat dan salah satu contohnya adalah PT. BPR Syariah Kota Mojokerto. BPRS adalah salah satu jasa keuangan bank syariah yang sesuai dengan ketentuan dalam undang-undang. BPRS merupakan lembaga keuangan yang menghubungkan pemodal (șạib mal) dan debitur (mudärib). Kehadiran BPRS telah banyak memberikan manfaat kepada masyarakat, baik individu maupun lembaga.

Persaingan yang sangat ketat karena banyaknya perbankan syariah PT. BPR Syariah Kota Mojokerto melakukan inovasi produk guna bersaing dengan bank syariah yang lain. Salah satunya adalah inovasi dalam sumber daya manusia, karena sumber daya manusia merupakan pelaku utama dalam menjalankan kegiatan yang dimiliki BPRS tersebut dalam tujuannya. Untuk mendapatkan kualitas sumber daya manusia yang kompeten di bidangnya, perusahaan menempuh berbagai cara, seperti budaya organisasi, lingkungan kerja, dan kompensasi. Menurut Siagian, kinerja karyawan dipengaruhi oleh beberapa faktor, yaitu gaji, lingkungan kerja, budaya organisasi, kepemimpinan dan motivasi kerja, disiplin kerja, kepuasan kerja, komunikasi dan faktor-faktor lainnya. ${ }^{4}$ Budaya organisasi adalah suatu sistem nilai bersama dalam suatu organisasi dan dijadikan pedoman untuk melakukan kegiatan untuk mencapai tujuan dalam organisasi. Budaya perusahaan dikembangkan oleh pendiri, pemimpin, dan anggota organisasi. ${ }^{5}$

Budaya PT. BPR Syariah Kota Mojokerto disimbolkan dari kata "SIFAT" yang merupakan singkatan dari șiddiq, yaitu bersifat jujur terhadap diri sendiri, orang lain dan Allah SWT; istiqāmah, yaitu bersifat teguh, sabar dan bijaksana; fațanah, yaitu profesional, disiplin, bekerja keras dan inovatif; amānah, yaitu rasa tanggung jawab dan saling menghormati dalam menjalankan tugas dan melayani nasabah; dan tabligh, yaitu bersikap mendidik, membina dan memotivasi pihak lain (para pegawai dan nasabah). Suatu perilaku dan efektivitas kinerja karyawan yang baik dapat dipengaruhi oleh budaya organisasi yang kuat dalam sebuah perusahaan. Dengan adanya budaya yang dianut dalam suatu perusahaan, maka kinerja karyawan akan berjalan dengan baik sekaligus akan membentuk karakter karyawan dengan sendirinya dalam menjalankan tugasnya dan mencapai tujuan dari sebuah perusahaan.

\footnotetext{
${ }^{2}$ Anwar Prabu Mangkunegara, Manajemen Sumber Daya Manusia, Cetakan Kedua (Bandung: PT Remaja Rosdakarya, 2010), 39.

${ }^{3}$ A. Maria, "Pengaruh Gaya Kepemimpinan, Pengembangan Sumber Daya Manusia dan Disiplin Kerja terhadap Kinerja Pegawai Sekretariat DPRD Provinsi Sulawesi Tengah", Jurnal Katalogis, Volume 1, Nomor 1 (2013).

${ }^{4}$ Siagian Sondang D, Manajemen Sumber Daya Manusia (Jakarta: Bumi Aksara, 2002), 91.

${ }^{5}$ Stephen P. Robbins, Prilaku Organisasi (Jakarta: PT. Indeks, Kelompok Gramedia, 2006), 112.
} 
Lingkungan kerja adalah segala sesuatu yang ada di sekitar para karyawan yang dapat mempengaruhi karyawan dalam menjalankan tugasnya. ${ }^{6}$ Seorang karyawan yang bekerja dalam suatu lingkungan yang baik dan mendukung karyawan untuk bekerja secara optimal, maka akan menghasilkan kinerja yang baik. Sebaliknya, jika lingkungan kerja kurang mendukung untuk bekerja, maka karyawan akan malas dan cepat lelah yang akan berpengaruh pada kinerja karyawan.

Selain itu, kompensasi juga menjadi faktor penunjang dalam menggerakkan kinerja karyawan. Kompensasi merupakan sebuah imbalan kepada karyawan baik secara langsung maupun tidak langsung atas pekerjaan yang dilakukan oleh karyawan untuk perusahaan. ${ }^{7}$ Tanpa adanya kompensasi dapat menurunkan nilai sumber daya manusia dalam sebuah perusahaan karena berkurangnya semangat untuk bersaing. Salah satu contoh kompensasi finansial di PT. BPR Syariah Kota Mojokerto adalah pemberian kompensasi berupa gaji, upah yang diberikan oleh perusahaan untuk karyawan atas pekerjaan yang dilakukan. Semakin tinggi tingkat kompensasi yang diberikan oleh perusahaan kepada karyawan akan medorong karyawan untuk bekerja dengan baik. Karyawan yang bekerja dengan baik akan menerima kompensasi yang lebih dari perusahaan tempat karyawan bekerja.

\section{Metode Penelitian}

Penelitian ini merupakan penelitian kuantitatif yang menekankan analisisnya pada data numerikal (angka) yang diolah dengan metode statistika. ${ }^{8}$ Obyek penelitian yang dipakai dalam penelitian ini adalah PT. BPR Syariah Kota Mojokerto. Populasi pada penelitian ini adalah semua karyawan PT. BPR Syariah Kota Mojokerto yang berjumlah 38 karyawan. ${ }^{9}$ Penelitian ini menggunakan sampel jenuh, yaitu suatu teknik pengumpulan sampel jika jumlah populasi relatif kecil atau suatu penelitian yang ingin membuat generalisasi dengan tingkat kesalahan yang sangat kecil, maka seluruh populasi dijadikan objek penelitian. ${ }^{10}$ Berdasarkan teori di atas maka dalam penelitian ini semua jumlah populasi karyawan yang berada di PT. BPR Syariah Kota Mojokerto dijadikan sampel, yaitu sebanyak 38 karyawan.

Sumber data yang digunakan dalam penelitian ini adalah sumber data primer dan sumber data sekunder. Sumber data primer dalam penelitian ini adalah berupa kuesioner. Sedangkan sumber data sekunder dalam penelitian ini adalah berupa dokumentasi dan bukubuku yang berhubungan dengan topik penelitian serta jurnal dan penelitian terdahulu.

Dalam menganalisis data yang diteliti, peneliti menggunakan alat analisis uji regresi linier berganda. Sebelum pengujian hipotesis akan dilakukan uji asumsi dasar berupa uji normalitas terhadap rangkaian data, dengan tujuan untuk mengetahui apakah populasi data berdistribusi normal atau tidak.

\footnotetext{
${ }^{6}$ Nitisemito S. Alek, Pengaruh Personalia, Edisi Kedua (Jakarta: Ghalia Indonesia, 2008), 74.

${ }^{7}$ Bejo Siswanto, Manajemen Tenaga Kerja Indonesia Pendekatan Administratif dan Operasional (Jakarta: PT Bumi Aksara, 2003), 35.

${ }^{8}$ Saifudin Azwar, Metode Penelitian (Yogyakarta: Pustaka Pelajar, 2004), 5.

${ }^{9}$ Komarul Alex Efendy, Wawancara, Mojokerto, 24 Januari 2020.

${ }^{10}$ Sulistiawati Paita, dkk, "Pengaruh Kompensasi dan Lingkungan Kerja Terhadap Kinerja Pegawai Melalui Motivasi Kerja pada Balai Pendidikan dan Pelatihan Keagamaan Manado “, Jurnal EMBA, Volume 3, Nomor 3 (September 2015), 686-687.
} 


\section{Budaya Organisasi dalam Islam}

Menurut Robbins, budaya organisasi adalah suatu sistem nilai kebersamaan dalam suatu organisasi yang menentukan tingkatan para karyawan untuk mencapai tujuan dalam suatu organisasi. ${ }^{11}$ Wirawan berpendapat bahwa budaya organisasi adalah suatu norma, nilai-nilai asumsi, kepercayaan, filsafat, kebiasaan organisasi yang dikembangkan oleh pendiri, pemimpin dan anggota organisasi, sehingga dengan adanya budaya organisasi maka akan mengatur pola pikir, sikap dan perilaku seorang anggota organisasi dalam melayani konsumen dan untuk mencapai tujuan organisasi. ${ }^{12}$

Islam memberikan penjelasan tentang budaya organisasi dalam sumber utama al-Quran dan Hadis. Kajian tentang budaya organisasi ini dimulai dengan mengambil penjelasan dari ayat al-Quran yang di dalamnya menjelaskan tentang keorganisasian. Allah berfirman dalam al-Quran:

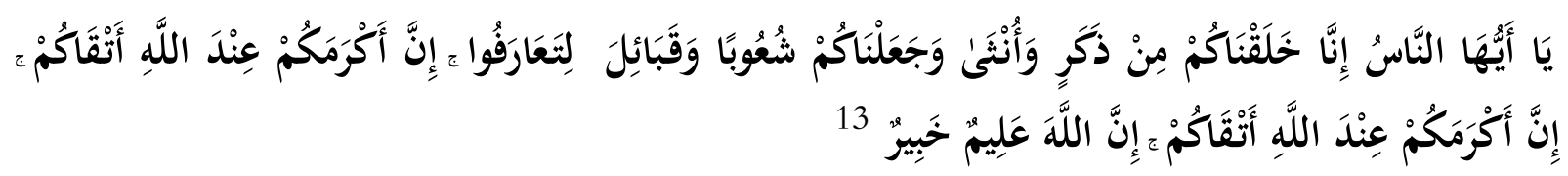

"Hai manusia, Sesungguhnya Kami menciptakan kamu dari seorang laki-laki dan seorang perempuan dan menjadikan kamu berbangsa-bangsa dan bersuku-suku supaya kamu saling mengenal. Sesungguhnya orang yang paling mulia di antara kamu di sisi Allah ialah orang yang paling takwa di antara kamu. Sesungguhnya Allah Maha mengetahui lagi Maha Mengenal.".14

Ayat di atas menjelaskan pentingnya melakukan suatu kegiatan secara bersama-sama demi efektifitas dan efisiensi pencapaian tujuan yang telah ditetapkan. Begitu pula dalam suatu organisasi perusahaan jika dalam suatu perusahaan melakukan suatu budaya organisasi secara bersama-sama akan berdampak pada efektifitas dan efisiensi dalam mencapai tujuan perusahaan.

Suatu perusahaan jika memiliki suatu budaya yang kuat akan bermanfaat untuk mengarahkan sebuah perilaku, karena akan membantu karyawan untuk melakukan pekerjaan yang lebih baik, sehingga setiap karyawan pada awal karirnya perlu mamahami dan bagaimana budaya tersebut terimplementasikan. Dengan adanya budaya organisasi dalam sebuah perusahaan akan menimbulkan sistem kebersamaan untuk melakukan tugas dan kewajiban sebagai karyawan. Sistem kebersamaan yang baik akan meningkatkan kinerja karyawan, sebaliknya jika sistem kebersamaan dalam suatu organisasi kurang baik maka akan menurunkan kinerja karyawan. Pada titik inilah budaya organisasi dalam suatu perusahaan sangat penting karena merupakan kebiasaan-kebiasaan yang diterapkan oleh perusahaan. Pada hakikatnya semua perusahaan memiliki budaya organisasi, namun tidak semua budaya organisasi sama kuatnya dalam mempengaruhi perilaku dan tindakan para karyawan.

\footnotetext{
${ }^{11}$ Stephen P. Robbins, Perilaku Organisasi, 115.

${ }^{12}$ Wirawan, Budaya dan Iklim Organisasi (Jakarta: Salemba Empat, 2007).

13 al-Quran, 49: 13.

14 Arif Muhammad, "Budaya Organisasi Lembaga Pendidikan dalam Perspektif Islam", Jurnal Ilmiah Prodi Pendidikan Agama Islam, Volume 11, Nomor 2 (Desember 2019), 116.
} 
Fungsi budaya organisasi sendiri memiliki lima fungsi, yaitu: ${ }^{15}$

1. Berperan untuk menetapkan suatu batasan dalam organisasi.

2. Suatu perasaan identitas bagi anggota organisasi.

3. Mempermudah timbulnya komitmen yang lebih luas.

4. Meningkatkan stabilitas sistem sosial.

5. Membentuk dan mengontrol sikap dan perilaku seorang karyawan.

\section{Faktor Lingkungan Kerja}

Lingkungan kerja adalah segala sesuatu yang ada di sekitar para pekerja, baik berbentuk fisik maupun non fisik yang dapat mempengaruhi pekerja dalam menjalankan pekerjaan yang dibebankan. ${ }^{16}$ Sedarmayanti mendefinisikan lingkungan kerja sebagai alat perkakas dan bahan yang dihadapi di lingkungan sekitarnya, metode kerjanya, serta pengatur kerjanya baik secara perseorangan maupun sebagai kelompok. ${ }^{17}$ Lingkungan kerja menurut Islam mencakup semua usaha dalam kegiatan manusia dalam sudut ruang dan waktu. Lingkungan ruang mencakup bumi, air, hewan dan tumbuh-tumbuhan serta semua yang ada di atas bumi.

Lingkungan kerja merupakan faktor penting yang dapat mempengaruhi kinerja seorang karyawan. Seorang karyawan bekerja di lingkungan yang baik dan nyaman serta mendukung untuk melakukan aktivitas pekerjaan yang dibebankan oleh karyawan akan menghasilkan kinerja yang baik. Sebaliknya, jika lingkungan kurang mendukung, maka karyawan akan malas bekerja dan cepat Lelah dan akan menjadikan kinerja karyawan tersebut akan menurun.

Secara tidak langsung lingkungan kerja dapat mempengaruhi kinerja seorang karyawan. Lingkungan kerja yang kondusif dan nyaman akan memberikan kenyamanan dan akan memberikan karyawan bekerja secara optimal. Lingkungan kerja mempengaruhi karyawan dalam menyelesaikan tugas dan tanggung jawab kepada organisasi. Lingkungan kerja yang baik akan membuat karyawan betah untuk bekerja dan melakukan aktivitas dalam menyelesaikan tugasnya. Lingkungan kerja akan mencakup hubungan kerja antara sesama karyawan dan hubungan kerja antar bawahan dan atasan serta lingkungan fisik tempat karyawan bekerja.

Manfaat dari lingkungan kerja yang optimal adalah jika suatu perusahaan menurunkan tingkat kecelakaan kerja, penyakit dan lain-lain, sehingga akan mampu meningkatkan kualitas para karyawaan, dan berakibat perusahaan akan semakin efektif. Maka dari peningkatanpeningkatan tersebut akan menghasilkan: ${ }^{18}$

1. Meningkatnya produktivitas perusahaan.

2. Meningatnya efisiensi dan kualitas karyawan.

3. Kompensasi yang diberikan kepada karyawan dan pembayaran langsung yang lebih rendah karena pengajuan klaim.

4. Menurunnya biaya-biaya asuransi karyawan.

5. Fleksisbilitas dan adaptabilitas yang lebih besar.

\footnotetext{
${ }^{15}$ Stephen P. Robbins, Perilaku Organisasi, 114.

${ }^{16}$ Nitisemito S. Alex, Pengaruh Personalia,76.

${ }^{17}$ Sedarmayanti, Manajemen Sumber Daya Manusia, Reformasi Birokrasi dan Manajemen Pegawai Negeri Sipil, Cetakan Kelima (Bandung: PT Refika Aditama, 2011), 84.

${ }^{18}$ Ririn Prihatin, "Pengaruh Kompensasi dan Lingkungan Kerja terhadap Kinerja Karyawan" (Skripsi--UNY Yogyakarta, 2011), 27.
} 
6. Seleksi tenaga kerja yang lebih baik karena meningkatnya citra perusahaan.

\section{Konsep Kompensasi}

Kompensasi adalah suatu bentuk imbalan finansial yang diperoleh karyawan atas jasajasa berwujud dan tujuan-tujuan yang diperoleh. ${ }^{19}$ Kompensasi adalah pendapatan yang berbentuk uang, barang langsung atau tidak langsung yang diterima oleh karyawan atas jasanya kepada karyawan. ${ }^{20}$ Menurut Veitzal dan Sagala, kompensasi adalah sesuatu yang diterima oleh karyawan sebagai pengganti kontribusi jasa yang mereka keluarkan untuk perusahaan. $^{21}$

Al-Quran menjelaskan tentang upah atau imbalan atau kompensasi:

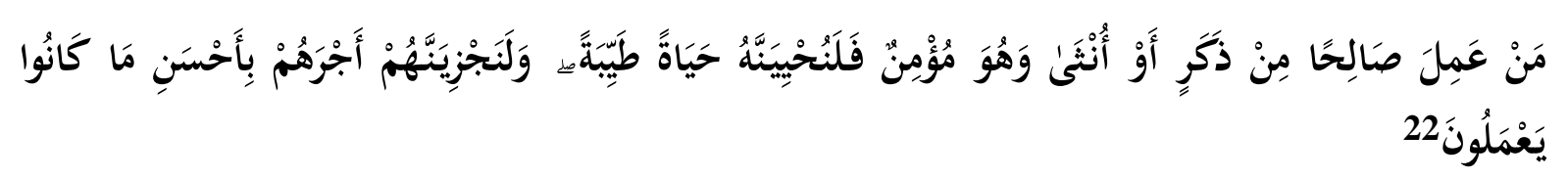

"Barangsiapa yang mengerjakan amal saleh, baik laki-laki maupun perempuan dalam keadaan beriman, maka sesungguhnya akan Kami berikan kepadanya kehidupan yang baik dan sesungguhnya akan Kami beri balasan kepada mereka dengan pahala yang lebih baik dari apa yang telah mereka kerjakan”.

Ayat di atas menelaskan bahwa barang siapa yang mengerjakan amalan saleh, seperti melakukan pekerjaan, Allah pasti akan membalas apa yang telah dikerjakan. Selian itu, ayat di atas menjelaskan bahwa tidak ada perbedaan gender dalam menerima upah atau balasan dari Allah atas pekerjaan yang kita lakukan, begitu pula tidak ada diskriminasi upah dalam Islam. Jika mereka melakukan pekerjaan yang halal maka balasan Allah di dunia, seperti kehidupan yang lebih baik atau rezeki yang halal dan balasan di akhirat, seperti mendapatkan pahala.

Penjelasan di atas menegaskan bahwa kompensasi adalah segala bentuk berupa imbalam dari perusahaan untuk karyawan sebagai imbalan atas jasa yang diberikan oleh karyawan. Berikut ini adalah komponen-komponen yang terdapat pada kompensasi yaitu:

1. Kompensasi finansial. Kompensasi ini adalah kompensasi yang berupa nominal uang yang harus dibayar perusahaan atas kerja dari karyawan. Kompensasi finansial dibagi menjadi dua, yaitu kompensasi langsung dan tidak langsung. Kompensasi langsung yaitu kompensasi perusahaan bersifat finansial langsung, seperti berupa gaji, tunjangan dan segala jenis pembayaran kepada karyawan yang dinominalkan dan diberikan pada karyawan secara langsung. Sedangkan kompensasi finansial tidak lansung yang diberikan dalam wujud bukan uang secara fisik, seperti pemberian asuransi kepada karyawan, pensiunan, dan lain-lain.

2. Kompensasi non finansial. Kompensasi ini adalah suatu jenis kompensasi tidak berupa nominal uang, biasanya berupa hal-hal yang tidak berwujud namun bisa dirasakan oleh

\footnotetext{
${ }^{19}$ Agus Sunyoto, Manajemen Sumber Daya Manusia (Jakarta: Badan Penerbit IPW, 2008), 69.

${ }^{20}$ Hasibuan Malayu S.P, Manajemen Sumber Daya Manusia (Jakarta: PT Bumi Aksara, 2002), 33.

${ }^{21}$ Veitzal dan Sagala Jauvani, Manajemen Sumber Daya Manusia untuk Perusahaan (Jakarta: Rajawali Press, 2009), 741

22 al-Quran, 16: 97.
} 
karyawan secara langsung, misalnya jam kerja yang fleksibel. Kompensasi ini dibagi menjadi dua, yaitu kompensasi yang berhubungan dengan pekerjaan dan kompensasi yang berhubungan dengan lingkungan kerja.

Adapun tujuan dari kompensasi adalah ${ }^{23}$ saling menjaga ikatan kerja sama antara karyawan dan perusahaan; balas jasa perusahaan kepada karyawan dapat memenuhi kebutuhan secara fisik dan lain-lain, sehingga dari balas jasa tersebut akan memperoleh kepuasan kerja karyawan; pengadaan efektif; motivasi; stabilitas karyawan; disiplin; pengaruh serikat buruh; pengaruh pemerintah.

\section{Konsep Kinerja}

Kinerja karyawan adalah upaya seorang individu untuk mencurahkan tenaga tertentu kepada pekerjaan. ${ }^{24}$ Kinerja karyawan adalah suatu pekerjaan yang dilakukan oleh seorang karyawan baik secara kualitas dan kuantitas yang dicapai dalam menjalankan tugasnya sesuai dengan tanggung jawab yang diberikan oleh perusahaan. ${ }^{25}$ Kinerja karyawan bersifat individual, setiap karyawan memiliki kemampuan yang berbeda-beda dalam mengerjakan tugas yang dibebankan. Untuk mengukur karyawan atas pekerjaan, pihak manajemen dapat melihat berdasarkan kinerja masing-masing karyawan. Suatu perusahaan yang memiliki seorang karyawan yang mempunyai kinerja baik, maka besar kemungkinan kinerja perusahaan tersebut akan baik, sehingga dari kinerja perusahaan yang baik tersebut akan memiiliki hubungan erat dengan kinerja perusahaan. Kinerja suatu pekerjaan yang menunjukkan suatu pencapaian target yang berkaitan dengan kuantitas dan kualitas dan waktu. Lalu dari pencapaian tersebut akan dipergunakan untuk memberikan kecakapan dan motivasi kepada karyawan.

Ada beberapa hal yang mempengaruhi kinerja, yaitu fasilitas kantor yang memadai dan sarana yang menunjang, lingkungan kerja yang nyaman, prioritas pekerjaan yang dibebankan kepada karyawan harus jelas, dan support pendapat antara karyawan dengan pemimpin.

\section{Gambaran Umum PT. BPR Syariah Kota Mojokerto Sejarah PT. BPR Syariah Kota Mojokerto}

Sesuai dengan Peraturan Daerah Nomor 6 Tahun 2009, Pemerintah Kota Mojokerto telah merintis pendirian lembaga keuangan syariah dengan nama PT. BPRS Kota Mojokerto. Berdasarkan Surat Izin Prinsip Nomor 13/66/Dpbs dan Surat Izin Operasional Nomor 13/44/KEP.GBI/DPG/2011 dari Bank Indonesia, maka sejak 1 Juli 2011 secara resmi PT. BPRS Kota Mojokerto yang beralamat di Jalan Mojopahit Nomor 382 beroperasi dengan modal dasar 8 miliar rupiah dengan modal awal yang telah disetor 2 miliar rupiah di mana komposisi kepemilikannya terdiri atas Pemerintah Kota Mojokerto sebesar $99 \%$ dan perorangan sebesar $1 \%$.

Seiring dengan perkembangannya, PT. BPRS Kota Mojokerto melalui Peraturan Daerah Nomor 12 Tahun 2013 dilakukan perubahan modal dasar dari 8 miliar rupiah menjadi 32 miliar rupiah dengan setoran modal di awal 2 miliar rupiah, dan sampai dengan akhir tahun

\footnotetext{
${ }^{23}$ Malayu S. P Hasibuan, Manajemen Sumber Daya Manusia, Edisi Revisi (Jakarta: Bumi Aksara, 2013$), 121$.

${ }^{24}$ Robbins dan Judge, Perilaku Organisasi, Edisi Duabelas (Jakarta: Salemba Empat, 2008), 162.

${ }^{25}$ Anwar Prabu Mangkunegara, Manajemen Sumber Daya Manusia, 48.
} 
2014 menjadi 11,3 miliar rupiah dan sampai dengan penelitian ini, modal disetornya menjadi 13,7 miliar rupiah.

\section{Produk-Produk PT. BPR Syariah Kota Mojokerto}

1. Jenis simpanan yang terbagi menjadi tujuh, yaitu:

a. Siedu Rencana IB yang merupakan tabungan berjangka dengan akad mudärabah untuk perencanaan masa depan yang dikelola berdasarkan prinsip syariah.

b. Sibarkah IB merupakan simpanan dalam bentuk tabungan yang dikelola berdasarkan prinsip mudärabah mutlaqah untuk tujuan dan bersifat umum.

c. Deposito Ummat IB, yaitu suatu bentuk investasi dengan prinsip bagi hasil.

d. Simple IB yang merupakan jenis tabungan untuk siswa dengan syarat mudah dan sederhana.

e. Tabungan Amanah IB yang digunakan untuk masyarakat umum.

f. Tabungan Qurban IB yang bertujuan untuk simpanan hewan kurban dan 'aqiqqah yang dikelola berdasarkan akad wadi' ah yad damānah.

g. Tabungan Al Madinah merupakan simpanan tabungan yang digunakan bagi nasabah yang berniat untuk menunaikan ibadah haji dan umrah secara terencana dan teratur sesuai dengan kemampuan dan jangka waktu yang diinginkan.

2. Jenis pembiayaan yang terbagi menjadi empat, yaitu:

a. Pembiayaan al-Amanah IB, yaitu pembiayaan sistem jual beli yang digunakan untuk modal kerja, investasi, dan konsumtif.

b. Pembiayaan al-Syirkah IB merupakan pembiayaan sistem bagi hasil yang digunakan untuk modal kerja.

c. Pembiayan Ijarah Al Faedah IB, yaitu pembiayaan dengan sistem sewa barang atau jasa yang digunakan untuk konsumtif dan investasi.

d. Pembiayaan Usaha Syariah IB yang merupakan produk kerjasama antar PT. BPRS Kota Mojokerto dengan BAZNAS Kota Mojokerto, Disperindag, Diskominaker, dan UPT Pasar Kota Mojokerto.

\section{Profil Responden}

Responden dalam penelitian ini adalah karyawan PT. BPRS Kota Mojokerto dengan jumlah sampel 38 karyawan. Komposisi responden dalam penelitian ini berdasarkan jenis kelamin laki-laki sebanyak 18 dan perempuan sebanyak 20. Responden menurut umur atau usia17-27 tahun sebanyak 15, 28-38 tahun sebanyak 10, 39-49 sebanyak 8, 50-60 tahun sebanyak 5. Responden berdasarkan tingkat pendidikan terakhir tingkat Diploma sebanyak 1, S-1 sebanyak 36, dan S-2 sebanyak 1. Responden berdasarkan lama bekerja yaitu 1-2 tahun sebanyak 9, 2-4 tahun sebanyak 10, 4-6 tahun sebanyak 11, > 6 tahun sebanyak 8 .

\section{Uji Validitas}

Uji validitas adalah suatu instumen dapat dikatakan valid jika alat tersebut dapat mengukur apa yang perlu diukur. Untuk menentukan valid tidaknya kuesioner dalam penelitian menggunakan perbandingan antara corrected item-total correlation dengan koefisien korelasi yang ditentukan sbesar $r=0,50$. Berikut ini adalah hasil uji variabel budaya 
organisasi $\left(\mathrm{X}_{1}\right)$, lingkungan kerja $\left(\mathrm{X}_{2}\right)$, kompensasi $\left(\mathrm{X}_{3}\right)$, dan kinerja $(\mathrm{Y})$. Budaya Organisasi $\left(X_{1}\right)$

Tabel 1.1. Budaya Organisasi (X1)

\begin{tabular}{|c|c|c|c|}
\hline \multicolumn{4}{|c|}{ Budaya Organisasi (X1) } \\
\hline Butir Pertanyaan & r hitung & r tabel & Keterangan \\
\hline 1 & 0,596 & 0,3120 & Valid \\
\hline 2 & 0,726 & 0,3120 & Valid \\
\hline 3 & 0,701 & 0,3120 & Valid \\
\hline 4 & 0,683 & 0,3120 & Valid \\
\hline
\end{tabular}

Sumber: data olah SPSS 20

Dari tabel 1.1. di atas dapat diketahui bahwa seluruh jumlah empat butir pertanyaan memiliki $\mathrm{r}$ hitung > nilai $\mathrm{r}$ tabel, maka dapat disimulkan bahwa semua butir pertanyaan valid atau dapat digunakan dalam penelitian.

Lingkungan Kerja $\left(X_{2}\right)$

Tabel 1.2. Lingkungan Kerja $\left(\mathrm{X}_{2}\right)$

\begin{tabular}{|c|c|c|c|}
\hline \multicolumn{4}{|c|}{ Lingkungan Kerja (X2) } \\
\hline Butir Pertanyaan & $\mathrm{r}$ hitung & $\mathrm{r}$ tabel & Keterangan \\
\hline 1 & 0,817 & 0,3120 & Valid \\
\hline 2 & 0,803 & 0,3120 & Valid \\
\hline 3 & 0,846 & 0,3120 & Valid \\
\hline
\end{tabular}

Sumber: data olah SPSS 20

Dari tabel 1.2. tersebut dapat diketahui bahwa seluruh jumlah tiga butir pertanyaan memiliki $r$ hitung > nilai $r$ tabel. maka dinyatakan valid dan dapat digunakan dalam penelitian ini.

Kompensasi $\left(X_{3}\right)$

Tabel 1.3. Kompensasi (X3)

\begin{tabular}{|c|c|c|c|}
\hline \multicolumn{4}{|c|}{ Kompensasi } \\
\hline ButirPertanyaan & $\mathrm{r}$ hitung & $\mathrm{r}$ tabel & Keterangan \\
\hline 1 & 0,875 & 0,321 & Valid \\
\hline 2 & 0,899 & 0,321 & Valid \\
\hline
\end{tabular}

Sumber: data olah SPSS 20

Dari tabel 1.3. tersebut dapat diketahui bahwa seluruh jumlah dua butir pertanyaan memiliki $r$ hitung > nilai $r$ tabel, maka dinyatakan valid dan dapat digunakan dalam penelitian ini. 
$\operatorname{Kinerja}(Y)$

Tabel 1.4. Kinerja (Y)

\begin{tabular}{|c|c|c|c|}
\hline \multicolumn{4}{|c|}{ Kinerja $(\mathrm{Y})$} \\
\hline Butir Pertanyaan & r hitung & r tabel & Keterangan \\
\hline 1 & 0,453 & 0,3120 & Valid \\
\hline 2 & 0,674 & 0,3120 & Valid \\
\hline 3 & 0,793 & 0,3120 & Valid \\
\hline 4 & 0,831 & 0,3120 & Valid \\
\hline
\end{tabular}

Sumber: data olah SPSS 20

Dari tabel 1.4. tersebut dapat diketahui bahwa seluruh jumlah empat butir pertanyaan memiliki $r$ hitung > nilai $r$ tabel, maka dinyatakan valid dan dapat digunakan dalam penelitian ini.

\section{Uji Normalitas}

Uji normalitas digunakan untuk menguji apakah nilai residual berdistribusi secara normal atau tidak. Metode uji normalitas yaitu dengan melihat data pada sumber diagonal grafik normal, yaitu dengan uji One Sample Kolomogrov-Smirnov. Berikut ini adalah hasil uji normalitas menggunakan Kolomogrov-Smirnov:

Gambar 1.1. Hasil Uji Normalitas Kolomogrov-Smirnov

One-Sample Kolmogorov-Smirnov Test

\begin{tabular}{llr} 
& & \multicolumn{2}{c}{$\begin{array}{c}\text { Unstandardized } \\
\text { Residual }\end{array}$} \\
\hline N & Mean & $\mathbf{3 8}$ \\
Normal Parameters & Std. Deviation & $\mathbf{1 . 2 8 6 1 3 4 4 1}$ \\
& Absolute & $\mathbf{1 8 6}$ \\
Most Extreme Differences & Positive & $\mathbf{0 9 8}$ \\
& Negative & $\mathbf{1 8 6}$ \\
Kolmogorov-Smirnov $Z$ & & $\mathbf{1 . 1 4 5}$ \\
Asymp. Sig. (2-tailed) & & $\mathbf{1 4 5}$ \\
\hline \multicolumn{2}{c}{ a. Test distribution is Normal. } \\
b. Calculated from data.
\end{tabular}

Berdasarkan hasil uji normalitas di atas, secara bersama-sama antara variabel budaya organisasi $\left(\mathrm{X}_{1}\right)$, lingkungan kerja $\left(\mathrm{X}_{2}\right)$, kompensasi $\left(\mathrm{X}_{3}\right)$ dan kinerja $(\mathrm{Y})$ didapatkan hasil sig sebesar 0,145, di mana hasil tersebut lebih besar dari taraf signifikan 0,05, sehingga dapat disimpulkan bahwa uji test normalitas pada penelitian ini adalah berdistribusi normal.

\section{Uji Regresi Linier Berganda}

Analisis regresi linier berganda digunakan untuk mengetahui apakah ada pengaruh antara dua variabel bebas atau lebih (budaya organisasi, lingkungan kerja, dan kompensasi) terhadap variabel terikat (kinerja) untuk membuktikan ada atau tidaknya hubungan fungsi 
antara dua variabel bebas atau lebih dengan satu variabel terikat. ${ }^{26}$

\section{Uji f (Simultan atau Serempak)}

Uji f bertujuan untuk menguji apakah ada pengaruh yang signifikan secara simultan atau bersama-sama dari budaya organisasi, lingkungan kerja dan kompensasi terhadap kinerja karyawan PT. BPRS Kota Mojokerto. Tingkat signifikansi atau kepercayaan menggunakan $\alpha$ $=5 \%$ atau 005 .

\section{Gambar 1.2. Hasil Uji f}

\begin{tabular}{|c|c|c|c|c|c|c|}
\hline \multicolumn{7}{|c|}{ ANOVA $^{a}$} \\
\hline Model & & Sum of Squares & df & Mean Square & $\mathrm{F}$ & Sig. \\
\hline \multirow{3}{*}{1} & Regression & 50.270 & 3 & 16.757 & 9.309 & $.000^{6}$ \\
\hline & Residual & 61.203 & 34 & 1.800 & & \\
\hline & Total & 111.474 & 37 & & & \\
\hline
\end{tabular}

Berdasarkan hasil uji di atas, diketahui bahwa f hitung adalah 9,309 sehingga f hitung > f tabel yaitu 9,309 > 2,87 dan nilai p-value (sig) sebesar 0,000 < kurang dari 0,05. Maka dapat diartikan bahwa pengaruh variabel bebas budaya organisasi $\left(\mathrm{X}_{1}\right)$, lingkungan kerja $\left(\mathrm{X}_{2}\right)$ dan kompensasi $\left(\mathrm{X}_{3}\right)$ berpengaruh secara simultan atau bersama-sama terhadap kinerja (Y) pada karyawan PT. BPR Syariah Kota Mojokerto.

\section{Uji t (Parsial atau Masing-masing Variabel)}

Uji t bertujuan untuk mengetahui apakah ada pengaruh yang signifikan secara parsial dari budaya organisasi, leingkungan kerja dan kompensasi terhadap kinerja karyawan PT. BPRS Kota Mojokerto.

Gambar 1.3. Hasil Uji t

\begin{tabular}{|c|c|c|c|c|c|c|c|c|c|c|c|}
\hline \multirow[b]{3}{*}{ Model } & & \multicolumn{5}{|c|}{ Coefficients $^{a}$} & & & \multirow{3}{*}{$\begin{array}{l}\text { Fraction Missing } \\
\text { Info. }\end{array}$} & \multirow{3}{*}{$\begin{array}{l}\text { Relative } \\
\text { Increase } \\
\text { Variance }\end{array}$} & \multirow{3}{*}{$\begin{array}{l}\text { Relative } \\
\text { Efficiency }\end{array}$} \\
\hline & & \multicolumn{2}{|c|}{ Unstandardized Coefficients } & $\begin{array}{l}\text { Standardized } \\
\text { Coefficients }\end{array}$ & \multirow[b]{2}{*}{$t$} & \multirow[b]{2}{*}{ Sig. } & \multicolumn{2}{|c|}{ Colline arity Statistics } & & & \\
\hline & & $\mathrm{B}$ & Std. Error & Beta & & & Tolerance & VIF & & & \\
\hline \multirow{4}{*}{1} & (Constant) & 4.069 & 2.446 & & 1.664 & .105 & & & & & \\
\hline & Budaya Organisasi & .402 & .158 & .386 & 2.546 & .016 & .701 & 1.426 & & & \\
\hline & Lingkungan Kerja & .463 & .167 & .420 & 2.763 & .009 & .698 & 1.433 & & & \\
\hline & Kompensasi & -.050 & .227 & -.034 & -.221 & .826 & .684 & 1.462 & & & \\
\hline
\end{tabular}

Diketahui dari hasil uji di atas:

1. Dari hasil uji pada variabel budaya organisasi $\left(X_{1}\right)$ terhadap $Y$ adalah sebesar $0,016<$ 0,05 dan nilai thitung $>\mathrm{t}$ tabel sebesar 2,546 > 2,028, sehingga dapat disimpulkan bahwa $\mathrm{H} 1$ diterima yang berarti terdapat pengaruh $\mathrm{X}_{1}$ terhadap $\mathrm{Y}$.

2. Dari hasil uji pada variabel lingkungan kerja $\left(X_{2}\right)$ terhadap $Y$ adalah, sebesar $0,009<$ 0,05 dan nilai t hitung $>\mathrm{t}$ tabel sebesar 2,763 > 2,028 sehinga dapat disimpulkan bahwa $\mathrm{H}_{2}$ diterima yang berarti terdapat pengaruh $\mathrm{X}_{2}$ terhadap $\mathrm{Y}$.

\footnotetext{
${ }^{26}$ Husain Usman dan Purnomo Setiadi Akbar, Pengantar Statistika (Jakarta: Bumi Aksara, 2008), 241.
} 
3. Dari hasil uji pada variabel kompensasi $\left(\mathrm{X}_{3}\right)$ terhadap $\mathrm{Y}$ adalah sebesar 0,826 > 0,05 dan nilai t hitung 0,221 < t tabel 2,028, sehingga dapat disimpulkan bahwa $\mathrm{H}_{3}$ ditolak yang berarti tidak terdapat pengaruh $\mathrm{X}_{3}$ terhadap $\mathrm{Y}$.

\section{Pengaruh Budaya Organisasi terhadap Kinerja Karyawan}

Dari hasil uji t pada variabel menunjukkan bahwa ada pengaruh positif dan signifikan secara parsial. Dari hasil uji t pada variabel budaya organisasi $\left(\mathrm{X}_{1}\right)$ terhadap kinerja $(\mathrm{Y})$ adalah sebesar $0,016<0,05$ dan nilai t hitung $>\mathrm{t}$ tabel sebesar 2,546 $>2,028$, sehingga dapat disimpulkan bahwa $\mathrm{H}_{0}$ ditolak dan $\mathrm{H}_{1}$ diterima yang berarti terdapat pengaruh budaya organisasi $\left(\mathrm{X}_{1}\right)$ terhadap kinerja karyawan (Y) PT. BPRS Kota Mojokerto.

Budaya organisasi merupakan suatu peraturan atau norma yang dikembangkan oleh pendiri dalam suatu organisasi. Jika semua faktor budaya organisasi melekat kuat dan positif kepada karyawan, maka akan sangat berpengaruh kepada kinerja karywan, begitu pula jika budaya organisasi tidak melekat pada karyawan maka secara signifikan tidak berpengaruh terhadap kinerja karyawan.

Suatu perusahaan jika memiliki suatu budaya yang kuat akan bermanfaat untuk mengarahkan sebuah perilaku, karena akan membantu karyawan untuk melakukan pekerjaan yang lebih baik, sehingga setiap karyawan pada awal karirnya perlu mamahami dan bagaimana budaya tersebut terimplementasikan. Dengan adanya budaya organisasi dalam sebuah perusahaan akan menimbulkan sistem kebersamaan untuk melakukan tugas dan kewajiban sebagai karyawan. Sistem kebersamaan yang baik akan meningkatkan kinerja karyawan, sebaliknya jika sistem kebersamaan dalam suatu organisasi kurang baik maka akan menurunkan kinerja karyawan. Maka, budaya organisasi dalam suatu perusahaan sangatlah penting karena merupakan kebiasaan-kebiasaan yang diterapkan oleh perusahaan. Pada hakikatnya semua perusahaan memiliki budaya organisasi, Namun tidak semua budaya organisasi sama kuatnya dalam mempengaruhi perilaku dan tindakan para karyawan.

\section{Pengaruh Lingkungan terhadap Kinerja Karyawan}

Lingkungan kerja adalah lingkungan yang mecakup lingkungan fisik dan non fisik. Lingkungan fisik contohnya adalah kebersihan, keamanan, dan lain-lain. Seorang karyawan jika bekerja di suatu perusahaan di lingkungan yang aman dan nyaman, serta lingkungan kerjanya bersih maka karyawan akan bekerja secara optimal dan akan menghasilkan kinerja baik, sebaliknya jika lingkungan kerjanya kurang memadai maka akan mempengaruhi kinerja karyawan seperti karyawan menjadi malas, mudah lelah, sehingga akan menjadikan kinerja karyawan tersebut akan menurun.

Sedangkan lingkungan non fisik contohnya seperti hubungan kerja antra karyawan dan hubungan karyawan dengan atasan atau pemimpin. Untuk menciptakan hubungan yang harmonis antara pimpinan dengan karyawan seperti menjaga hubungan baik antar karyawan dengan pemimpin, serta berkomunikasi dalam suatu team kerja dan bersikap ramah kepada sesama karyawan. Maka dari penjelasan di atas dapat disimpulkan bahwa lingkungan kerja dapat mempengaruhi kinerja karyawan, hal tersebut terbukti dengan hasil uji yang menunjukkan lingkungan kerja berpengaruh positif dan signifikan terhadap kinerja karyawan. Dari hasil uji pada variabel lingkungan kerja $\left(\mathrm{X}_{2}\right)$ terhadap kinerja $(\mathrm{Y})$ adalah sebesar 0,009 < 
0,05 dan nilai t hitung $>\mathrm{t}$ tabel sebesar 2,763 > 2,028 sehinga dapat disimpulkan bahwa $\mathrm{H}_{0}$ ditolak dan $\mathrm{H}_{2}$ diterima yang berarti terdapat pengaruh lingkungan kerja $\left(\mathrm{X}_{2}\right)$ terhadap kinerja karyawan (Y) PT. BPRS Kota Mojokerto.

\section{Pengaruh Kompensasi terhadap Kinerja Karyawan}

Hasil uji t menunjukkan bahwa antara variabel kompensasi tidak berpengaruh secara positif dan signifikan terhadap kinerja. Dari hasil uji pada variabel kompensasi $\left(\mathrm{X}_{3}\right)$ terhadap $\mathrm{Y}$ adalah sebesar $0,826>0,05$ dan nilai $\mathrm{t}$ hitung $0,221<\mathrm{t}$ tabel 2,028, sehingga dapat disimpulkan bahwa $\mathrm{H}_{0}$ diterima dan $\mathrm{H}_{3}$ ditolak yang berarti tidak ada pengaruh kompensasi $\left(\mathrm{X}_{3}\right)$ terhadap kinerja karyawan (Y) PT. BPRS Kota Mojokerto.

Kompensasi merupakan imbalan yang diberikan kepada karyawan oleh perusahaan atas jasa-jasa yang diberikan. Jenis kompensasi ada dua, yaitu kompensasi finansial dan kompensasi non finansial. Kompensasi perusahaan bersifat finansial langsung seperti berupa gaji, tunjangan dan segala jenis pembayraran kepada karyawan yang dinominalkan dan diberikan pada karyawan secara langsung. Sedangkan kompensasi finansial tidak langsung yang diberikan dalam wujud bukan uang secara fisik, seperti pemberian asuransi kepada karyawan, pensiunan, dan lain-lain.

Jenis kompensasi secara finansial yang diberikan oleh PT. BPRS Kota Mojokerto dengan cara memberikan gaji kepada karyawan setiap bulan atas jasa yang diberikan kepada perusahaan. Meskipun PT. BPRS Kota Mojokerto memberikan kompensasi yang adil kepada setiap karyawan, tetapi tidak berpengaruh terhadap kinerja karyawan. Sedangkan kompensasi non finansial, seperti menyedikan fasilitas yang mendukung dan lingkungan kerja yang kondusif. Meskipun fasilitas yang mendukung dan lingkungan kerja yang kondusif di PT. BPRS Kota Mojokerto tidak mempengaruhi kinerja karyawan. Mungkin dari faktor lain yang mempengaruhi kinerja karyawan.

\section{Pengaruh Budaya Organisasi, Lingkungan Kerja, dan Kompensasi terhadap Kinerja Karyawan}

Berdasarkan hasil perhitungan yang telah dilakukan oleh peneliti dalam uji f diketahui bahwa f hitung adalah 9,309 sehingga f hitung > f tabel yaitu 9,309 > 2,87, dan nilai p-value (sig) sebesar 0,000 < kurang dari 0,05. Maka dapat diartikan bahwa pengaruh variabel bebas budaya organisasi $\left(\mathrm{X}_{1}\right)$, lingkungan kerja $\left(\mathrm{X}_{2}\right)$ dan kompensasi $\left(\mathrm{X}_{3}\right)$ berpengaruh secara simultan atau bersama-sama terhadap kinerja (Y) pada karyawan PT. BPRS Kota Mojokerto.

Kinerja adalah suatu pekerjaan yang dilakukan oleh seorang karyawaan secara kualitas dan kuantitas yang dicapai dalam menjalankan tugasnya sesuai dengan tanggung jawab yang diberikan. Kinerja karyawan PT. BPRS Kota Mojokerto dapat terus meningkat apabila didukung oleh beberapa faktor dari perusahaan seperti budaya organisasi, lingkungan kerja, dan kompensasi.

Budaya organisasi adalah suatu peraturan yang dikembangkan oleh pemimpin untuk mengatur pola piker, sikap dan perilaku seorang anggota karyawan untuk mencapai tujuan perusahaan. Budaya PT. BPRS Kota Mojokerto disimbolkan dari kata "SIFAT", yang merupakan singkatan dari siddiq, istiqämah, fatānah, amānah dan tablïgh. Sedangkan lingkungan kerja adalah segala sesuatu yang ada di sekitar karyawan yang dapat 
mempengaruhi karyawan dalam menjalankan tugas dari perusahaan. Lingkungan yang ada di perusahaan apabila mendukung karyawan untuk bekerja secara optimal akan menghasilkan kinerja yang baik, sebaliknya jika lingkungan kerja kurang mendukung akan membuat karyawan menjadi malas, mudah lelah, dan lain sebagainya. Salah satu contoh aspek pengukuran lingkungan kerja PT. BPRS Kota Mojokerto adalah ruang gerak yang meliputi aspek fasilitas kerja yang tersedia sudah cukup memadai untuk mendukung aktivitas kerja. Pengaruh lingkungan kerja terhadap kinerja karyawan sangat erat hubungannya dalam proses pencapaian tujuan perusahaan. Dengan kata lain, lingkungan kerja dapat mempengaruhi kinerja karyawan.

Adapun kompensasi adalah imbalan yang diberikan kepada karyawan atas jasa-jasa yang diberikan untuk perusahaan. Komponen-komponen yang terdapat pada kompensasi terdiri dari kompensasi yang bersifat finansial, yang terdiri dari kompensasi langsung dan tidak langsung; dan kompensasi bersifat non finansial, yang terdiri dari kompensasi yang berhubungan dengan pekerjaan dan kompensasi yang berhubungan dengan lingkungan kerja. Salah satu contoh kompensasi finansial PT. BPRS Kota Mojokerto yaitu kompensasi langsung yang berupa gaji, upah yang diberikan oleh perusahaan untuk karyawan, atas pekerjaan yang dilakukan oleh karyawan.

\section{Kesimpulan}

Dari hasil penelitian di atas dapat disimpulkan bahwa pertama, ada pengaruh positif dan signifikan secara parsial variabel budaya organisasi $\left(\mathrm{X}_{1}\right)$ terhadap kinerja karyawan (Y) PT. BPRS Kota Mojokerto, yaitu sebesar 0,016 < 0,05 dan nilai t hitung > t tabel sebesar 2,546 > 2,028. Kedua, dari hasil uji pada variabel lingkungan kerja $\left(\mathrm{X}_{2}\right)$ terhadap Y adalah, sebesar $0,009<0,05$ dan nilai t hitung $>\mathrm{t}$ tabel sebesar 2,763 > 2,028 maka ada pengaruh positif dan signifikan secara parsial variabel lingkungan kerja $\left(\mathrm{X}_{2}\right)$ terhadap kinerja karyawan (Y) PT. BPRS Kota Mojokerto. Ketiga, tidak ada pengaruh positif dan signifikan secara parsial variabel kompensasi $\left(\mathrm{X}_{3}\right)$ terhadap kinerja (Y) PT. BPRS Kota Mojokerto. Hal ini dibuktikan dari hasil uji pada variabel kompensasi $\left(\mathrm{X}_{3}\right)$ terhadap $\mathrm{Y}$ adalah sebesar 0,826 > 0,05 dan nilai $\mathrm{t}$ hitung $0,221<\mathrm{t}$ tabel 2,028, sehingga dapat disimpulkan bahwa $\mathrm{H}_{0}$ diterima dan $\mathrm{H}_{3}$ ditolak. Keempat, berdasarkan hasil perhitungan yang telah dilakukan oleh peneliti dalam uji f diketahui bahwa f hitung adalah 9,309 sehingga $f$ hitung $>\mathrm{f}$ tabel yaitu 9,309> 2,87 dan nilai p-value (sig) sebesar 0,000 < kurang dari 0,05. Maka dapat diartikan dalam uji $\mathrm{f}$ bahwa pengaruh variabel bebas budaya organisasi $\left(\mathrm{X}_{1}\right)$, lingkungan kerja $\left(\mathrm{X}_{2}\right)$ dan kompensasi $\left(\mathrm{X}_{3}\right)$ berpengaruh secara simultan atau bersama-sama terhadap kinerja (Y) pada karyawan PT. BPRS Kota Mojokerto.

\section{Daftar Rujukan}

Alek, Nitisemito S. Pengaruh Personalia, Edisi Kedua. Jakarta: Ghalia Indonesia, 2008. Azwar, Saifudin. Metode Penelitian. Yogyakarta: Pustaka Pelajar, 2004.

Amirullah. Metodelogi Penelitian Manajemen. Malang: Bayumedia Publising, 2013. Arikunto. Prosedur Penelitian Suatu Pendekatan Praktek. Jakarta: Rineka Apta, 2007. Usman, Husain dan Purnomo Setiadi Akbar. Pengantar Statistika. Jakarta: Bumi Aksara, 2008. 
Sondang, Siagian, D. Manajemen Sumber Daya Manusia. Jakarta: Bumi Aksara, 2002.

Hasibuan, Malayu S.P. Manajemen Sumber Daya Manusia Edisi Revisi. Jakarta: Bumi Aksara, 2013.

Robbins dan Judge. Perilaku Organisasi, Edisi Duabelas. Jakarta: Salemba Empat, 2008.

Veitzal dan Sagala Jauvari. Manajemen Sumber Daya Manusia untuk Perusahaan. Jakarta: Rajawali Press, 2009.

Mangkunegara, Anwar Prabu. Manajemen Sumber Daya Manusia, Cetakan Kedua. Bandung: PT Remaja Rosdakarya, 2010.

Maria, A. "Pengaruh Gaya Kepemimpinan, Pengembangan Sumber Daya Manusia dan Disiplin Kerja terhadap Kinerja Pegawai Sekretariat DPRD Provinsi Sulawesi Tengah", Jurnal Katalogis, Volume 1, Nomor 1 (2013).

Muhammad, Arif. "Budaya Organisasi Lembaga Pendidikan dalam Perspektif Islam”. Jurnal Ilmiah Prodi Pendidikan Agama Islam, Volume 11, Nomor 2 (Desember 2019).

Malayu, Hasibuan SP. Manajemen Sumber Daya Manusia. Jakarta: PT Bumi Aksara, 2002.

Prihatin, Ririn. "Pengaruh Kompensasi dan Lingkungan Kerja terhadap Kinerja Karyawan". Skripsi--UNY Yogyakarta, 2011.

Robbins, Stephen P. Prilaku Organisasi. Jakarta: PT. Indeks Kelompok Gramedia, 2006.

Siswanto, Bejo. Manajemen Tenaga Kerja Indonesia Pendekatan Administratif dan Operasional. Jakarta: PT Bumi Aksara, 2003.

Sugiyono. Metode Penelitian. Bandung: Alfabeta, 2003.

Paita, Sulistiawati, dkk., "Pengaruh Kompensasi dan Lingkungan Kerja Terhadap Kinerja Pegawai Melalui Motivasi Kerja pada Balai Pendidikan dan Pelatihan Keagamaan Manado “, Journal EMBA, Volume 3, Nomor 3 (September 2015).

Sunyoto, Agus. Manajemen Sumber Daya Manusia. Jakarta: Badan Penerbit IPW, 2008.

Wirawan. Budaya dan Iklim Organisasi. Jakarta: Salemba Empat, 2007.

Sedarmayanti. Manajemen Sumber Daya Manusia, Reformasi Birokrasi dan Manajemen Pegawai Negeri Sipil, Cetakan Kelima. Bandung: PT Refika Aditama, 2011. 